\title{
Tapasztalataink a rekeszsérvek laparoszkópos sebészetével
}

\author{
Csucska Máté dr. ${ }^{1}$ - Sumeet K. Mittal dr. ${ }^{2}$ - Kovács Balázs dr. ${ }^{1}$ \\ Kremzer Tamás dr. ${ }^{1}$. Ozorai Lilla dr. ${ }^{1}$ \\ Lóderer Zoltán dr. ${ }^{1}$. Juhász Árpád dr. ${ }^{1,3}$ \\ ${ }^{1}$ Markusovszky Egyetemi Oktatókórház, Szombathely \\ ${ }^{2}$ Norton Thoracic Institute, St. Joseph's Hospital and Medical Center, Phoenix, Arizona, USA \\ ${ }^{3}$ Jász-Nagykun-Szolnok Megyei Hetényi Géza Kórház-Rendelőintézet, Szolnok
}

Bevezetés: A hiatus hernia egy anatómiai betegség; gyakoribb előfordulása idősebbeknél jelezheti, hogy a betegség idővel előrehalad, súlyosbodik. Elhanyagolt esetben szövődmények alakulhatnak ki, melyek növelhetik a perioperatív mortalitást.

Célkitüzés: A laparoszkópos hiatusrekonstrukciók sebészetében szerzett mútéti tapasztalataink ismertetése mellett igyekeztünk statisztikailag alátámasztható korrelációt találni a rekeszizom-defektus anatómiai paraméterei, valamint a betegek életkora között.

Módszer: Retrospektív tanulmányunk keretében elemeztük azon betegeinket, akik laparoszkópos hiatus hernia műtéten estek át egy 58 hónapos (2016. január-2020. október) vizsgálati periódus során. A rekeszi defektus méreteit endoszkópos vonalzóval a mútét közben megmértük, a hiatus oesophagei felszínét standard matematikai formula segítségével számoltuk ki. A sürgősséggel mútétre kerülő betegeink adatait külön elemeztük.

Statisztikai analizis: A defektus mérete és a betegek életkora és magassága közötti korrelációt a Spearman-féle ró $(\rho)$-korreláció segítségével állapítottuk meg. A szignifikanciaszint $\mathrm{p} \leq 0,05$ volt.

Eredmények: Az elektív csoportban 142 operált páciensből 47 beteg mérési adatai feleltek meg a kritériumoknak. Az átlagéletkor $64,7 \pm 12,7$ év volt, 33 páciens volt nő (70,2\%), az átlagos testtömegindex $28,8 \pm 5,5 \mathrm{~kg} / \mathrm{m}^{2}$ volt. A defektus haránt átmérője és felszíne szignifikáns pozitív korrelációt mutatott a betegek életkorával $(\mathrm{p} \leq 0,05)$. Akut indikációval 5 beteg került mútétre; a defektus méretét illetően hasonló eredményeket tapasztaltunk, mint az elektív csoportnál, 2 esetben azonban súlyos szövődmények alakultak ki.

Következtetés: A betegség mögött húzódó anatómiai okok jobb megértése és a megfigyeléseink alapján módosított sebésztechnika reményeink szerint csökkentheti a hosszú távú kiújulások számát a jövőben. Az időben elvégzett elektív beavatkozás alacsonyabb mortalitással, kevesebb szövődménnyel és rövidebb hospitalizációval jár együtt.

Orv Hetil. 2021; 162(19): 754-759.

Kulcsszavak: hiatus hernia, intrathoracalis gyomor, laparoszkópos antirefluxmútét

\section{Our experience with the laparoscopic surgery of hiatal hernias}

Introduction: Hiatal hernia is an anatomical disease, and the higher incidence for elderly patients suggests that it is progressing over time. Neglected cases can cause serious complications, raising perioperative mortality.

Objective: We are presenting our experience in laparoscopic hiatal reconstructions. Our main goal is to find a statistical correlation between the anatomical parameters of the hiatal defect and the patients age.

Method: Surgical data were reviewed retrospectively for patients who underwent laparoscopic hiatal hernia repair between January 2016 and October 2020. Dimensions of the hiatal defect were measured intraoperatively with an endoscopic ruler. The defect size was calculated using a standard formula. The acute surgeries were analyzed as a separate arm of the study.

Statistical analysis: The correlation between the patients age and the size of the defect were calculated using Spearman's rho $(\rho)$ correlation. The level of significance was $p \leq 0.05$.

Result: In the elective group, out of 142 patients 47 met the inclusion criteria. The mean age was $64.7 \pm 12.7$ years, 33 patients were women, and the mean BMI was $28.8 \pm 5.5 \mathrm{~kg} / \mathrm{m}^{2}$. Patient age showed significant positive correlation with the transverse dimension and the size of the hiatal defect. 5 patients underwent surgery due to acute indications. We found similarities in the size of the defects; at 2 patients we documented severe complications. 
Conclusions: A better understanding of the underlying anatomical disorders and the consecutively modified surgical technique will hopefully reduce the long-term recurrencies in the future. The elective surgery performed in the right time results in lower mortality, less complications and shorter hospitalization time.

Keywords: hiatal hernia, intrathoracic stomach, laparoscopic anti-reflux surgery

Csucska M, Mittal SK, Kovács B, Kremzer T, Ozorai L, Lóderer Z, Juhász Á. [Our experience with the laparoscopic surgery of hiatal hernias]. Orv Hetil. 2021; 162(19): 754-759.

(Beérkezett: 2020. november 9.; elfogadva: 2020. november 30.)

\section{Rövidítések}

$\mathrm{CT}=$ (computed tomography) számítógépes tomográfia; GERD = (gastroesophageal reflux disease $)$ gastrooesophagealis refluxbetegség; $\mathrm{HEF}=\mathrm{a}$ hiatus oesophagei felszíne; $\mathrm{R}=\mathrm{a}$ rekeszi defektus hosszanti átmérője; SAGES = (Society of American Gastrointestinal and Endoscopic Surgeons) Amerikai Gastrointestinalis és Endoszkópos Sebészek Társasága; T = a rekeszi defektus haránt átméróje

A csuszamlásos (I. típusú) rekeszizomsérv definíció szerint a gyomor vagy más hasüregi szerv mellüregbe vándorlását jelenti a hiatus oesophagein keresztül. Ezen anatómiai defektus etiológiája továbbra sem tisztázott, több elméletet is publikáltak az elmúlt évtizedekben [1]. A legtöbb rekeszsérv tünetmentes, igen gyakran mellékleletként kerül leírásra egyéb indikációjú radiológiai vagy endoszkópos vizsgálat során [2]. Gyakori megfigyelés azonban, hogy nagy méretú - endoszkóposan és nagy felbontású manometriával mérve $5 \mathrm{~cm}$-t meghaladó, azaz „óriás” - rekeszsérvek idősebb betegeknél kerülnek felismerésre [3]. Ez alapján joggal feltételezhetjük, hogy sebészeti beavatkozás nélkül idővel a betegség előrehalad; megfigyelések szerint szélsőséges, ritka esetekben súlyos, életet veszélyeztető szövődmények (úgymint intrathoracalis gyomor, kizáródott rekeszsérv) is kialakulhatnak.

Az Amerikai Gastrointestinalis és Endoszkópos Sebészek Társaságának (Society of American Gastrointestinal and Endoscopic Surgeons - SAGES) jelenleg is érvényben lévő ajánlása [4] szerint a mútéti beavatkozás lényege a rekeszszárak közelítésén alapul, csökkentve ezzel a defektust, valamint megfelelő méretű nyílást biztosítva a nyelőcső számára. A több mint két évtizedes laparoszkópos sebészi tapasztalat ellenére a hosszú távú kiújulás a mai napig gyakori megfigyelés [5]. A közelmúltban bemutatott, hálóval történô megerôsítést használó technikák javítottak ugyan a rövid távú eredményeken, a hoszszú távú kiújulás tekintetében azonban nem hoztak szignifikáns javulást $[6,7]$.

A rekeszi defektus növekedésének elégtelen ismerete hozzájárulhat ezekhez a dokumentáltan rossz sebészeti eredményekhez. Számtalan tanulmány fókuszált a múltban a kiújulás mértékének csökkentésére, azonban csak kevés az anatómiai defektus változásának megértésére. A patofiziológia jobb megértése és az ezen alapuló mó- dosított sebésztechnika reményeink szerint hatékonyan csökkentheti a kiújulások számát a jövőben.

Ezen retrospektív tanulmányunk célkitûzése kettôs. Ismertetjük a laparoszkópos primer antirefluxmütétek és rekeszi rekonstrukciók során szerzett tapasztalatainkat, demonstrálva a rekeszi defektus méretét és ennek összefüggését a beteg antropomorfológiai paramétereivel és életkorával. Bemutatjuk továbbá az elhanyagolt, szövődményes, sürgősséggel felvételre került betegeinket, akik kizáródott hiatus hernia miatt kerültek akut mútétre.

\section{Anyag és módszer}

\section{Vizsgálati alanyok (1.ábra)}

Minden, laparoszkópos jóindulatú betegség miatt nyelőcsőmütéten átesett betegünk adatait prospektíven vezetett, jelszóval védett adatbázisban rögzítettük. Ezt az adatbázist felhasználva azon alanyok adatait gyújtöttük ki, akiknél tervezetten történt a beavatkozás, az elsődleges indikáció a gastrooesophagealis refluxbetegség (GERD) és/vagy a csuszamlásos rekeszsérv volt, illetve megfelelően dokumentáltuk a hiatus oesophagei mért paramétereit egy 58 hónapos (2016. január-2020. október) vizsgálati periódus során (elektív mútéti csoport).

A pácienseket a vizsgálatunk ezen részéből kizártuk 1) nem megfelelő dokumentáció esetén, 2) sürgősségi beavatkozás okán végzett mútétek esetén, 3 ) ha életkoruk 18 év alatt volt, vagy 4 ) ismételt (redo-) mútéten estek át. Nem kerültek a vizsgálati halmazba továbbá, ha az 5) elsődleges indikáció eltért a fent ismertetettől (úgymint achalasia miatt végzett Heller-myotomia vagy cricopharyngealis myotomia), vagy a mútét során rekeszi rekonstrukció nem történt (például laparoszkópos Roux-Y gastricus bypass esetén).

Külön táblázatban rögzítettük és vizsgáltuk a fenti periódus során sürgősséggel felvett, akutan vagy halasztott sürgősséggel megoperált betegeinket. Az indikáció itt minden esetben a panaszokat okozó intrathoracalis gyomor vagy kizáródott rekeszsérv formájában került rögzítésre (sürgősségi mútéti csoport).

A betegek demográfiai és antropomorfológiai paramétereit, valamint az elérhetô mútéti adatokat mindkét csoportban kigyújtöttük és elemeztük. 


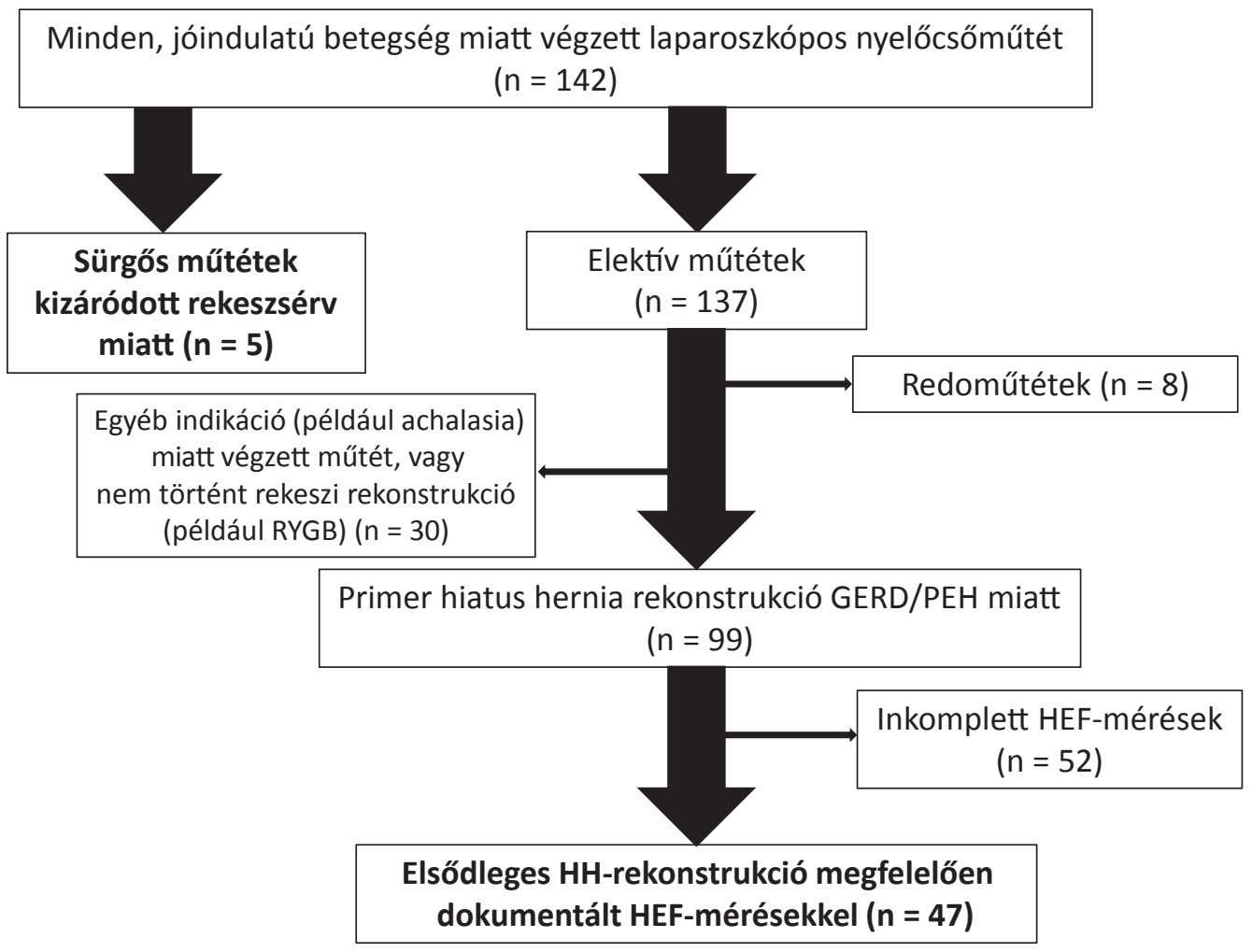

1. ábra

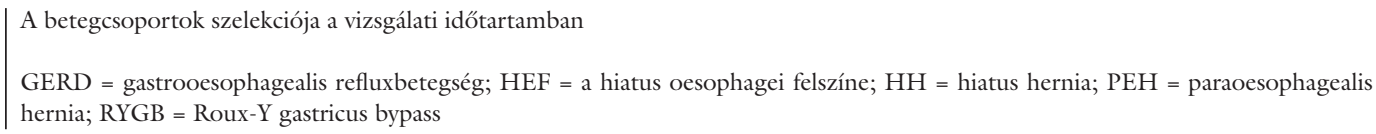

\section{Sebésztechnika és a rekeszi paraméterek}

A laparoszkópos hiatusrekonstrukciót számtalan tanulmány ismertette korábban nagy részletességgel [8]. Röviden: típusos francia portolást követően felkerestük és szkeletizáltuk a gyomor nagygörbületét, valamint circumferentialisan kipreparáltuk a sérvtömlőt a hiatus oesophageire tartva. A nyelőcső, valamint a rekesz mobilizálását követően endoszkópos vonalzóval megmértük a hosszanti $(\mathrm{R}$ - a rekeszi commissurától a pars flaccidáig terjedő) és a haránt (T - a két rekeszi él közötti legnagyobb) átmérőt, és a mütétet követően a fent említett táblázatban rögzítettük a hiatus oesophagei dimenzióit (2. ábra).

A hiatus oesophagei felszínét (HEF) egy formula segítségével számítottuk ki, melyet először Granderath ismertetett [9].

$$
\mathrm{HEF}=(\pi \times \mathrm{R} \times \text { alpha } 0 / 180) \times \mathrm{R} / 2
$$$$
\text { ahol az alfa-szög }=2 \times(\arcsin [\mathrm{T} / 2] / \mathrm{R})
$$

Hogy elkerüljük a nyelőcső megrövidüléséből származó szövődményeket, kiterjedt mediastinalis dissectiót végeztünk. Ezt követően az intraabdominalis nyelőcső hossza a 2-3 cm-t el kellett, hogy érje, csak ezt követően kezdtük meg a mütét rekonstrukciós szakaszát. A pneumoperitoneum okozta fals érték elkerüléséért az alkalmazott csúcsnyomást a meghatározás idejére csökkentettük.
Rekonstruáltuk a rekeszi defektust anteroposterior irányban a nyelőcső körül 6 óránál, valamint 2 óránál behelyezett nem felszívódó öltésekkel. A bioabszorbens (Bio-A) háló alternatívájaként, különösen a nagy méretű sérvkapukat autológ dermisgrafttal erősítettük meg, a munkacsoportunk által korábban már ismertetett és publikált módon [10]. Végül elvégeztük a fundoplikációt, az előzetesen felállított indikációnak megfelelően megválasztott technikával.

\section{Statisztikai analizis és adatbázis-kezelés}

Minden, számításokhoz kigyưjtött és felhasznált adatot jelszóval védett Excel-táblázatban (Microsoft, Redmond, WA, USA) rögzítettünk. A demográfiai adatokat átlag \pm standard deviáció szerint prezentáltuk. A paraméterek közti korrelációhoz a Spearman-féle ró $(\rho)$ korrelációt használtuk. A szignifikanciaszintet a $\mathrm{p} \leq 0,05$ értéken állapítottuk meg. A statisztikai vizsgálatokhoz az SPSS statisztikai szoftver 22.0-ás verzióját használtuk (IBM, Armonk, NY, USA).

\section{Eredmények}

Összesen 47 beteg felelt meg a vizsgálati kritériumoknak a primer elektív, antirefluxműtétes csoportban, és 5 páciens esetében történt sürgős beavatkozás (1.ábra). 


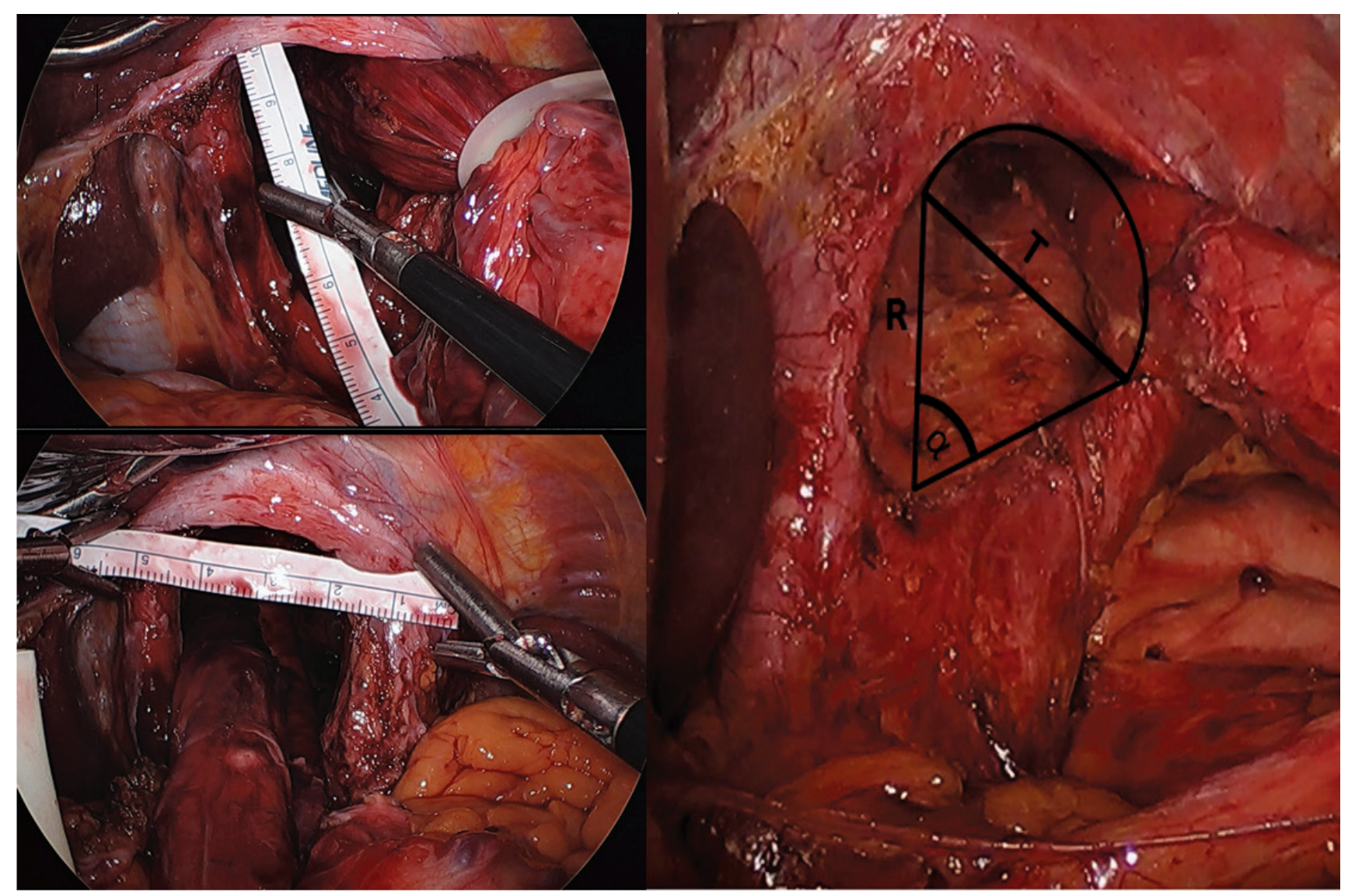

2. ábra $\mid \begin{aligned} & \text { A mútét során alkalmazott mérési technika } \\ & \mathrm{R}=\text { hosszanti átmérő; } \mathrm{T}=\text { haránt átmérō }\end{aligned}$

1) Az elektív csoportban az átlagéletkor $64,7 \pm 12,7$ év volt, 33 páciens volt nő (70,2\%), és az átlagos testtömegindex $28,8 \pm 5,5 \mathrm{~kg} / \mathrm{m}^{2}$ volt. Az elsődleges indikáció minden esetben GERD és vagy paraoesophagealis vagy csuszamlásos hiatus hernia volt. A mediastinalis dissectiót követően az intraabdominalis nyelőcsőhossz minden esetben elérte vagy meghaladta a $2 \mathrm{~cm}$-t, így Collis szerinti nyelő́csőplasztikát egy esetben sem végeztünk. Minden beteg átesett primer laparoszkópos hiatusrekonstrukción. Különösen nagy méretű sérvkapu miatt 3 $(6,4 \%)$ beteg esetében végeztünk megerősítést a mütéti területen autológ dermisgrafttal. Részletesebb beavatkozási adatok az 1. táblázatban láthatók.

$\mathrm{Az}$ átlagos mütéti időtartam $88,4 \pm 34,5$ perc volt. Az ebben a csoportban operált betegeink esetében mútét közben komplikációt nem észleltünk. Az átlagos hospitalizációs időintervallum $1,30 \pm 1,00$ nap volt, és egyik beteg esetében sem volt szükség intenzív osztályos felvételre.

$\mathrm{Az}$ átlagos haránt átmérő (T) 2,8 $\pm 0,9 \mathrm{~cm}$, az átlagos hosszanti átméró $(\mathrm{R})$ 4,5 $\pm 0,7 \mathrm{~cm}$, az átlagos defektusfelszín (HEF) 6,5 $\pm 3,0 \mathrm{~cm}^{2}$ volt. A betegek életkora szignifikáns pozitív korrelációt mutatott a haránt átmérôvel ( $\mathrm{rs}=0,32, \mathrm{p}=0,03)$ és a rekeszi defektus méretével ( $\mathrm{rs}=0,30, \mathrm{p}=0,04)$. A betegek testtömegindexével ( $\mathrm{rs}=-0,74, \mathrm{p}=0,62)$, valamint magasságával $(\mathrm{rs}=-0,51$, $\mathrm{p}=0,29)$ a rekeszi defektus mérete nem mutatott szignifikáns korrelációt.

2) A sürgósséggel mütétre került csoportban az átlagéletkor $73,4 \pm 4,16$ év volt, 3 páciens $(60 \%)$ volt nő. A betegdokumentáció alapján $3 / 5(60 \%)$ beteg esetében korábban leírásra került endoszkóposan $5 \mathrm{~cm}$-t meghaladó hiatus hernia, de sebészeti rekonstrukció az akut mútétet megelőzően egy esetben sem történt. Az átlagos mútéti idő $162 \pm 19,24$ perc volt. A gyomor több mint kétharmada minden esetben a mellüregben helyezkedett el,

1. táblázat |A betegcsoportokon végzett mútéti beavatkozások részletezése

\begin{tabular}{lcc}
\hline Mútéti beavatkozás & $\begin{array}{c}\text { Elektív csoport } \\
\mathrm{n}(\%)\end{array}$ & $\begin{array}{c}\text { Sürgősségi csoport } \\
\mathrm{n}(\%)\end{array}$ \\
\hline A páciensek száma & 47 & 5 \\
Elsődleges hiatusrekonstrukció & $47(100)$ & $3(60)$ \\
Fundoplikáció & $47(100)$ & $3(60)$ \\
$\quad$ Nissen-fundoplikáció & $2(4,3)$ & $0(0)$ \\
Toupet-fundoplikáció & $43(91,5)$ & $2(40)$ \\
$\quad$ Dor-fundoplikáció & $2(4,3)$ & $1(20)$ \\
Autológ dermisgraft behelyezése & $3(6,4)$ & $1(20)$ \\
$\begin{array}{l}\text { Oesophagectomia sec. Torek- } \\
\text { mútét }\end{array}$ & $0(0)$ & $2(40)$ \\
\hline
\end{tabular}


a rekeszi defektus mérete minden esetben meghaladta a $8 \mathrm{~cm}^{2}$-t. $3(60 \%)$ esetben az összenövések okozta nehézségek ellenére a mútéti technika lépései megegyeztek az elektív beavatkozások során leírtakkal. 2 (40\%) betegnél azonban konverzióra kényszerültünk, ezekben az esetekben a nyelöcső részleges elhalása miatt Torek-féle oesophagectomia történt fundusreszekcióval kiegészítve. Intenzív terápiás ápolásra 3 beteg szorult, az átlagos hospitalizációs idő 7,8 $\pm 1,3$ nap volt. Posztoperatív 30 napon belül 1 korai haláleset $(20 \%)$ történt aspirációs pneumonia okozta súlyos szeptikus állapot miatt az egyik, Torek-mútéten átesett betegünknél.

\section{Megbeszélés}

A rekeszizom a szerepe szerint elválasztja a negatív nyomású mellüreget a pozitív nyomású hasüregtől. A centrum tendineum a diaphragma középső részén nyitott ejtőernyő formájában van rögzítve, a rekesz izmos összeköttetéseivel a gerinchez és a mellkasfalhoz van kötve. A természetes nyílások a rekeszizmon biztosítják a neurovascularis és a zsigeri struktúrák áthaladását a hasüregbe és fordítva. A nyelőcső a mellkas felől az ún. hiatus oesophagein keresztül lép át a hasüregbe. A 20. században kadáverek vizsgálata során ezen struktúra 11 különböző anatómiai variációját írták le, az esetek döntő többségében a jobb oldali rekeszszár a nyelőcsövet megkerülve alkotott anatómiai egységet [11, 12]. A közelmúltban Zifan és mtsai [13] optikai szekcionáló mikroszkóppal modellezték a hiatus oesophagei myoarchitecturájának 3 dimenziós modelljét. Bemutatták, hogy a jobb rekeszszár a nyelőcső körül ellipszis alakú hurkot képez, nem pedig rendezett körgyưrút. Normál anatómiai viszonyok között a nyelőcső ebben a hurokban rögzül, a phrenooesophagealis szalagrendszernek köszönhetően. Ez a strukturális egység fontos szerepet játszik az alsó nyelőcső́-záróizom megerősítésében, a GERD elleni védekezésben. A rekeszszárak és a phrenooesophagealis ligamentum meggátolják továbbá a hasüregi szervek mellüregbe jutását is. Amennyiben ezen struktúra anatómiai integritása bármilyen okból sérül, rekeszizomsérv (hiatus hernia) alakul ki. A legtöbb esetben a proximális gyomor (I. típusú) vándorol a mellüregbe. Ez általában inkompetens alsó nyelőcsősphincteri funkcióval és kóros refluxbetegséggel jár együtt. Amennyiben a sérv előrehalad, a gyomor nagyobb része, valamint egyéb hasüregi szervek is a mellüregbe juthatnak, komplexebb rekeszsérveket (II., III., IV. típus) okozva. Általánosságban elmondható, hogy a tangencionálisan $5 \mathrm{~cm}$-t meghaladó, ún. óriás hiatus herniák megjelenése idősebb betegekre jellemző [3]. A sürgősséggel operált betegeink magasabb átlagéletkora ezt az adatot támasztja alá.

A mútéti rekonstrukció tervezésekor és kivitelezésekor fontos szempont a rekeszi defektus mérete - ezen adat perioperatív becslésére több kísérlet is történt a múltban. Ouyang és mtsai [14] sikeresen kvantifikálták a HEF-et CT-képek segítségével, de a tanulmányban méréseiket nem hasonlították össze intraoperatív mérési eredményekkel. Granderath és mtsai [9] ezzel szemben mútét közben mérték a defektus méretét, és megfogalmaztak ajánlásokat a rekonstrukciós stratégiák meghatározására, de az ismertetett variációk csak a különböző hálók használatára korlátozódtak. A sebészeti beavatkozás legkritikusabb pontja a rekeszi defektus rekonstrukciója. A hosszú távú kiújulás egyes adatok szerint hálók használata mellett is igen magas értéket érhet el, illetve bizonyos hálók használata katasztrofális következményekkel járhat. A közelmúltban bemutatott, Koetje és mtsai által írt közlemény [6], valamint a Tam és mtsai által prezentált metaanalízis bemutatta [15], hogy a hálók rutinszerú használata nem csökkenti szignifikánsan a hosszú távú kiújulás mértékét. A tanulmányunkban ismertetett tapasztalataink és méréseink alapján az alapvetô sebésztechnika módosítását javasoljuk. Mivel az életkorral a haránt átmérő szignifikánsan növekszik, és a Saad és mtsai által közölt tanulmány [16] szerint a rekeszizomsérv kiújulása az anterior területen a leggyakoribb (több mint $60 \%$ ), a jelenleg elfogadott anteroposterior irányú varratok alkalmazása mellett, rutinszerúen öltésekkel megerősítjük a centrum tendineum melletti vékony izomköteget is a nyelőcső körül 2 óránál behelyezett öltéssel (3. ábra).

$\mathrm{Az}$ irodalomban régóta vitatott téma a rekeszsérvek korai rekonstrukciójának kérdése. A 2002-ben Stylopoulos és mtsai által bemutatott vizsgálat a szoros utánkövetést javasolta a rekeszsérves betegek esetében a tünetek lassú progressziója és a sürgósségi komplikációk ritka előfordulása (1,1\%) miatt [17]. Egy közelmúltban Polomsky által bemutatott tanulmány [18] szerint azonban az intrathoracalis gyomor miatt végzett mútétek esetében a mortalitás 20 -szoros értéket mutat az elektív beavatkozásokkal szemben. Az utóbbi adatok fényében a tervezett beavatkozások elvégzése ajánlott lehet a legtöbb esetben. Adataink alapján feltételezzük, hogy az életkor előrehaladásával a rekeszsérv is - több mint valószínú, hogy - progrediál. A fent ismertetett, sürgősséggel mütétre kerülő betegek adatai alátámasztják, hogy az elhanyagolt rekeszsérvek intenzív osztályos kezelést

Nyelőcső

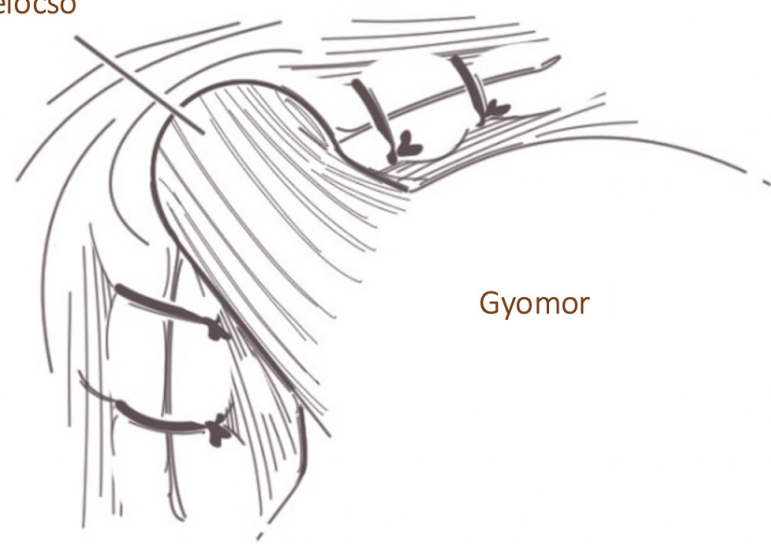

3. ábra | A módosított sebésztechnika sematikus ábrája 
tehetnek szükségessé, és életet veszélyeztető komplikációkat okozhatnak. A kezelőorvosnak ezen megfigyeléseket minden esetben figyelembe kell vennie, amikor egy terápiás döntés megszületik.

Tanulmányunknak vannak ugyanakkor korlátai is. Adatainkat korlátozza az alacsony esetszámú kohorsz, mely összehasonlító vizsgálatot, illetve komplexebb statisztikai elemzést nem tett lehetővé az elektív és a sürgős csoport között. Tanulmányunk további gyengesége, hogy nem tartalmaz utánkövetéses adatot, a módszer validitása jelenleg nem bizonyított. Mútéttechnikai módosító javaslatunk, valamint az elektív mútét javallata elsősorban megfigyeléseinken alapul, további prospektív multicentrikus tanulmányok szükségesek a módosított sebésztechnika hatékonyságának igazolására.

\section{Következtetés}

Összefoglalásul elmondható, hogy a sürgősségi indikációkkal végzett mútétek súlyos szövődményekkel, elhúzódó kórházi kezelésekkel járhatnak, így az elektív beavatkozás elvégzése a nagy méretü hiatus herniák esetén tünetmentes esetben is megfontolandó. Az ezzel kapcsolatos mútéti kockázat felmérése tapasztalt, felső tápcsatornai beavatkozásokban jártas sebész és a vele együtt dolgozó, az ilyen irányú beavatkozásokban szintén magas szintû́ tudással rendelkező team feladata. A véletlen leletként leírt és a kivizsgálás alapján okkal meg nem operált elváltozások folyamatos követését javasoljuk. Az általunk bemutatott módosított sebésztechnika kórélettani és anatómiai megfigyeléseken alapul, reményeink szerint csökkentheti a betegség kiújulását a jövőben.

Anyagi támogatás: A kézirat elkészítéséhez a szerzők anyagi támogatást nem kaptak.

Szerzői munkamegosztás: Cs. M.: A kézirat megírása, adatok gyújtése, a statisztikai számítások elvégzése. S. K. M.: A kézirat alapjául szolgáló ötlet kidolgozója, konzultáns sebészprofesszor. K. B., K. T., O. L.: Adatok gyújtése, feldolgozása, rendezése. L. Z.: Osztályvezető föorvos, értékes tanácsokkal segítette a dolgozat elkészültét. J. Á.: A kézirat véleményezője, a tanulmány vezetője és előkészítője. A cikk végleges változatát valamenyi szerző elolvasta és jóváhagyta.

Érdekeltségek: A szerző́knek nincsenek érdekeltségeik.

\section{Köszönetnyilvánítás}

A szerzők köszönetüket fejezik ki prof. dr. Márkus Béla tanár úrnak a kézirat elkészítésében nyújtott segítségéért, hasznos tanácsaiért, a mútétek során nyújtott szakmai támogatásáért.

\section{Irodalom}

[1] Weber C, Davis CS, Shankaran V, et al. Hiatal hernias: a review of the pathophysiologic theories and implication for research. Surg Endosc. 2011; 25: 3149-3153.

[2] Kahrilas PJ, Kim HC, Pandolfino JE. Approaches to the diagnosis and grading of hiatal hernia. Best Pract Res Clin Gastroenterol. 2008; 22: 601-616.

[3] Gray DM, Kushnir V, Kalra G, et al. Cameron lesions in patients with hiatal hernias: prevalence, presentation, and treatment outcome. Dis Esophagus 2015; 28: 448-452.

[4] Kohn GP, Price RR, DeMeester SR, et al. Guidelines for the management of hiatal hernia. Surg Endosc. 2013; 27: 44094428.

[5] Suppiah AP, Sirimanna S, Vivian J, et al. Temporal patterns of hiatus hernia recurrence and hiatal failure: quality of life and recurrence after revision surgery. Dis Esophagus 2017; 30: 1-8.

[6] Koetje JH, Oor JE, Roks DJ, et al. Equal patient satisfaction, quality of life and objective recurrence rate after laparoscopic hiatal hernia repair with and without mesh. Surg Endosc. 2017; 31: 3673-3680.

[7] Oelschlager BK, Pellegrini CA, Hunter JG, et al. Biologic prosthesis to prevent recurrence after laparoscopic paraesophageal hernia repair: long term follow-up from a multicenter, prospective, randomized trial. J Am Coll Surg. 2011; 213: 461-468.

[8] Blake AM, Mittal SK. Long-term clinical outcomes after intrathoracic stomach surgery: a decade of longitudinal follow-up. Surg Endosc. 2018; 32: 1954-1962.

[9] Granderath FA, Schweiger UM, Pointner R. Laparoscopic antireflux surgery: tailoring the hiatal closure to the size of hiatal surface area. Surg Endosc. 2007; 21: 542-548.

[10] Kovács B, Orosz M, Csucska M, et al. A novel approach to reinforcement in giant hiatal hernias. Case Rep Surg. 2018; 2018: 9069430 .

[11] Listerud MB. Details of interest and controversy in the anatomy of the esophageal hiatus and hiatal hernia. Surg Clin North Am. 1964; 44: 1211-1216.

[12] Bowden RE, El-Ramli HA. The anatomy of the oesophageal hiatus. Br J Surg. 1967; 54: 983-989.

[13] Zifan A, Kumar D, Cheng LK, et al. Three-dimensional myoarchitecture of the lower esophageal sphincter and esophageal hiatus using optical sectioning microscopy. Sci Rep. 2017; 7: 13188.

[14] Ouyang W, Dass C, Zhao H, et al. Multiplanar MDCT measurement of esophageal hiatus surface area: association with hiatal hernia and GERD. Surg Endosc. 2016; 30: 2465-2472.

[15] Tam V, Winger DG, Nason KS. A systematic review and metaanalysis of mesh vs suture cruroplasty in laparoscopic large hiatal hernia repair. Am J Surg. 2016; 211: 226-238.

[16] Saad AR, Velanovich V. Anatomic observation of recurrent hiatal hernia: recurrence or disease progression? J Am Coll Surg. 2020; 230: 999-1007.

[17] Stylopoulos N, Gazelle GS, Rattner DW. Paraesophageal hernias: operation or observation? Ann Surg. 2002; 236: 492-500.

[18] Polomsky M, Hu R, Sepesi B, et al. A population-based analysis of emergent vs. elective hospital admissions for an intrathoracic stomach. Surg Endosc. 2010; 24: 1250-1255.

(Juhász Árpád dr., Szolnok, Tószegi út 21., 5000 e-mail: juhasz.arpadimre@gmail.com)

A cikk a Creative Commons Attribution 4.0 International License (https://creativecommons.org/licenses/by/4.0/) feltételei szerint publikált Open Access közlemény, melynek szellemében a cikk bármilyen médiumban szabadon felhasználható, megosztható és újraközölhetö, feltéve, hogy az eredeti szerző és a közlés helye, illetve a CC License linkje és az esetlegesen végrehajtott módosítások feltüntetésre kerülnek. (SID_1) 